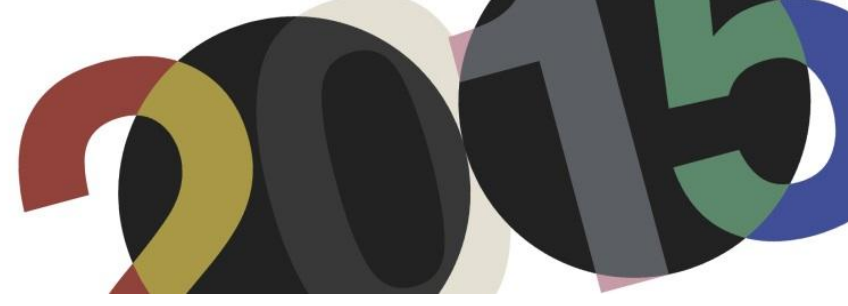

DOI: http://dx.doi.org/10.4995/LC2015.2015.942

\title{
Ronchamp in the spotlight. The feature of a shocking building in the 50s journals
}

\author{
F.J. Casas Cobo \\ College of Architecture and Digital Design, Dar Al Uloom University, Riyadh, Saudi Arabia \\ Escuela Técnica Superior de Arquitectura de Madrid
}

\begin{abstract}
Although currently it is largely accepted that Chapelle Notre-Dame du Haut at Ronchamp is one of the milestones in Le Corbusier's works, there is no less agreement in saying that it was one of the most controversial of his works and one turning point in modern architecture, not only in terms of digging a grave for functionalism but to opening a window to a wide bunch of architects and works that would have been excluded from history and maybe forever otherwise. In order to recall its importance, we must look back to how architectural journals featured Ronchamp in the mid fifties as, on one hand, Le Corbusier was not a young architect but a very well known and respected one with an international reputation and therefore, it was not easy to criticize his works and, on the other hand, Ronchamp was such a shocking building for many colleagues who had no choice but writing about it that somehow they were between the Devil and the deep blue sea.
\end{abstract}

Keywords: Ronchamp; debate; journals; historiography, contemporary; criticism.

\section{Introduction}

One of the most beautiful polemics arose when Ronchamp was completed was one due to Ernesto Nathan Rogers and Giulio Carlo Argan in Casabella in 1955. If Rogers supported the so called new trajectory of Le Corbusier's career, Argan criticized it upon a moral basis by pointing that Le Corbusier was an agnostic architect who, therefore and according to Argan, should have not accepted the commission to build a church. The moral issue shifted to a more cultural approach when Giancarlo di Carlo jumped in the debate in the pages of Casabella continuitá. Bruzo Zevi in L'architettura had joined the discussion previously contributing to reinforcing the idea of Ronchamp as consistent with modern architecture while James Stirling offered an explanation about it occupying a middle ground in The Architectural Review whereas Nikolaus Pevsner wrote a less benevolent text about the Chapelle.

Not only Casabella welcomed Ronchamp displaying it in its cover but also Architectural Forum and other journals such us Architectural Design or L'Architecture d'aujourd'hui gave significant room to the event. Even three years later in Arts\&Architecture, where few attention had been paid to Ronchamp as they were busy showcasing case studies and buildings related to industry manufactures, John Jacobus Jr. will review a book on Le Corbusier and months later Craig Ellwood himself will write "The Machine and Architecture" giving both texts new perspectives on the new path Ronchamp had already opened.

It is very unlikely that architects, historians or critiques change their minds and admit to having said something they regret afterwards. A rare example might be Robert Venturi, who apologized for his disdain towards Mies van der Rohe some twenty years later after writing his famous "Less is a bore" but not much can be said about those who openly criticized Le Corbusier's Ronchamp and eventually succumbed to stick to the most extended acceptance of this building as one, although conspicuous and consequence of a unique genius mind, still consistent with the variety of ideas supported and embraced by him. However, it can be tracked and it compones the skeleton of our more recent historiography if we follow up later books by Rogers or Zevi and those written 
by Drew, Jacobus or Joedicke in the $60 \mathrm{~s}$ and $70 \mathrm{~s}$ disembarking in the recent Tafuri, Frampton, Curtis, Colquhoun, Cohen and so on histories of modern architecture which homogeneously underline the importance of Ronchamp as part of the -otherwise imposible to frame- broad, varied and rich modern architecture.

\section{Ronchamp in the 50s journals}

As mentioned before, one of the most passionate debates was the one hold between Ernesto Nathan Rogers and Giulio Carlo Argan. All begun with the article "Il metodo di Le Corbusier e la forma nella "Chapelle de Ronchamp"”, published in Casabella in 1955. In this somehow enthusiastic text, E. N. Rogers writes with great veneration towards Le Corbusier's last work. However, it can not be said that Rogers is only paying a tribute to him as there is some criticism in his text. In particular, Rogers is not very satisfied with the angle between north and east walls although he prays indulgence to that as if it was a very small failure from someone thought to be perfect, a tiny imperfection. More over, in the interior, the writer claims to dislike the use of the red color in fire wrapping the altar but these two details will be mostly the only ones to be pointed out as partially wrong whereas the rest of the text will be laudatory and in order to exalt Le Corbusier's work as a masterpiece.

In this sense, one of the most interesting themes that Rogers touches in the article is, of course, the apparent contradiction in Le Corbusier's trajectory as this was, to everybody's eyes, a work that would not fit in easily. Rogers does not bow his head and sanctions that Ronchamp can not be seen or understood as part of a linear process -an historic one- as it was of an irreductible originality and synthesized his individual and very original personality and history.

For Rogers, it does not represent any contradiction the fact that Le Corbusier had championed the machine and his approach to a new world where industry and machinist ideas commanded it. Even more, he challenges Le Corbusier's imitators to follow him from now onwards as Ronchamp was undoubtedly an almost unreachable model to imitate.

It was not a surprise how Rogers did not hesitate in applauding this controversial last work of Le Corbusier from the very beginning as this position was consistent with previous articles he wrote but although it can not be said that he was brave jumping in, it is true that his text was one of the most supportive ${ }^{1}$ and led to a fruitful debate afterwards.

Le Corbusier himself published a brief text following Rogers' pages. The author underlines the palimpsest nature of the chapel in a terrain where different constructions had been replacing others after successive wars and describes the building itself with some references to materials, construction, the four horizons and its determining character over the form of the building which is not the aim of its description as he wants to put the light on other aspects such us psychological sensations.

\footnotetext{
${ }^{1}$ Nor Architectural Forum nor Casabella was the first journal in publishing Ronchamp in September 1955; Architectural Design did it in July 1955. At the same time as Architectural Forum and Casabella, Architectural Review published "From Garches to Jaoul: Le Corbusier as Domestic Architect in 1927 and 1953”, the controversial article by James Stirling who, eventually some months later, would write on Le Corbusier's Ronchamp for Architectural Review in March 1956. Conspicuously, French L'Architecture d'aujourd'hui will not do likewise until April 1957 but Ronchamp would be front page.
} 
Very soon after, in the first issue of 1956, Casabella publishes Giulio Carlo Argan's response to Rogers in the first pages under the form of letter to the journal ${ }^{2}$ in which he does not only show his surprise (and disagreement) with Rogers but also with Bruno Zevi, who had posed himself in favor of Ronchamp through the pages of L'architettura, the journal he founded and directed since mid 1955. In "Verso un solo linguaggio", Zevi explains the inclusive journal's position with regard to rationalist trends and organicist proposals which included Italian examples but explained through a parallelism with international architecture and, in particular, with Alvar Aalto as leader of the organic European movement, according to Zevi, and Le Corbusier's Ronchamp, a building that, in his opinion, was not rationalist and did not follow any of the five points towards a new architecture but nevertheless was consistent with the natural evolution of rationalism and had adopted the demanding of internal space, articulated volumes and had enriched the figurative dictionary, being all of the previous ideas part of what the new organic movement demanded.

As in the case or Rogers, no one wast taken by surprise when Zevi supported Le Corbusier's surprising building though not him but Giuseppe Samonà would be the one who would sign a later article ${ }^{3}$ devoted to Ronchamp. Worth mention here that Zevi had been devising an inclusive discourse since the foundation of Associazione per l'Architettura Organica (A. P. A. O.) more than ten years before in 1944.

Continuing with Argan's reply to Rogers, Argan admits that he has not visited Ronchamp (Rogers had) and he had only seen what Casabella had featured but he did not expect his opinion may change as it was grounded in moral basis rather than formal. The truth is that, despite the extremely long letter to complain and argue against Rogers' article, this is the only regret anybody may stick with after all.

Argan accused Ronchamp of being insolently anti-historic, not in the sense of the history of religious architecture but with regard to the history of modern architecture. Needless to say at this point that the debate on history was on the table and Italian architects played a remarkable role on it. Following this debate, a new one involving again Ernesto Nathan Rogers would take place amid Architectural Review and Casabella on Neoliberty and the supportive attitude of Rogers to some Italian architects who outlined a revival on liberty style but, later on, Rogers (within his office BBPR) will build the astonishing Torre Velasca which would lead to further and fierce dispute reaching CIAM and its further dissolution. Argan teased Rogers' description of the way to the altar through soft ramps and uneven floor and compared architectural functionalism and machine-àhabiter with a "machine to worship and pray" in what might be a religious functionalism.

The central point of Argan's disagreement lied in Le Corbusier as figurehead of modern architecture turned into a kind of spiritual leader ${ }^{4}$ for the society and serving an anti-modern purpose as this was. Argan admitted that he was not against the idea of non religious architects working for religious institutions but, and this is the key of the question, to exalt the ideals of these institutions by designing a building which enabled to this great excitement being the author, Le Corbusier, a secular.

Some few months later, probably the minimum posible between the printing outs of the successive journals, Rogers would answer Argan's letter with another letter dated 16 February 1956. Rogers did not surrender to the argument of Argan with regard to the moral ground of modern architecture, which was something he always

\footnotetext{
2 Argan, Giulio Carlo: "Dibattito su alcuni argomenti moral dell'architettura”. In Casabella continuita, Nr. 209, JanuaryFebruary 1956, p. 1-4.

${ }^{3}$ Samoná, Giuseppe:'Lettura della Cappella a Ronchamp". In L'architettura, June 1956.

${ }^{4}$ Argan reminds the calvinist origins of Le Corbusier's family. Le Corbusier's indifference towards religion was not a secret as he claimed himself to be an agnostic but not as atheist and that, despite no small debate amid the clients, did not avoid him to get the commission to build the Chapel.
} 
agreed with, but waved a flag on Le Corbusier's creativity and extraordinary vitality to interprete different themes along all his career in an unbiased way.

Rogers will answer every and each of the many arguments thrown by Argan regardless they were historical, moral, ethical or stylist. It is not the aim of this paper to review all the parallelisms and deep analysis that Argan uses in an attempt to convince his colleague, or otherwise, as they are too many and include references as different as Mondrian, Baroque, Gothic, Gropius or Einstein. Nevertheless, the differentiation between functionalism and rationalism, an apparently overcome debate, is worthy to be explained. For Rogers, the functionalist architect does not operate amid the boundaries of pure logic but the one who incorporates the inherent vibrations of historical structures and translate those in a synthesis of utility and beauty with the symbols of his own and personal figurative language. This position was very closed to what Bruno Zevi and L'architettura were supporting and, needles to say, is a tailored ad hoc definition for Le Corbusier's last building.

In this sense, Rogers will be more explicit and enthusiastic and will place Le Corbusier in a position very close to nature, comparing him with Alvar Aalto and Frank Lloyd Wright, as he poses Le Corbusier wanted to merge architecture with nature reaching a complete fusion. It is true that Le Corbusier explained here and there his interest towards nature and the surroundings of the chapel, the idea of the four horizons, the collection of rain water and the way to approach the building from the countryside. However, it can not be said that this was his first concern always -as it was for other architects under the label of organic architecture- and thus Rogers seemed to be going further in this defense than what should be reasonable.

Another key contribution to the debate is the one made by James Stirling in The Architectural Review in March 1956. In "Le Corbusier's Chapel and the Crisis of Rationalism", Stirling relates a brief introduction where he points out the division between art and technology that has confronted the ideological base of Modern Movement since its origin, specifically when Art Nouveau was born and engineering was tackling new typologies at the end of 19th century. It is quite interesting that he bridges the gap between America and Europe explaining how functionalism is linked to construction and industrial processes in America whereas in Europe still stands the humanist essence related to the function. Thus, somehow, gives an explanation of the search of space and form that allows that something as awkward as Ronchamp occurs in Europe, something that Stirling will claim to "may possibly be the most plastic building ever erected in the name of modern architecture".

Stirling will not spend time addressing questions related to moral as Argan did and Rogers accepted to response. On the contrary, he analyzed why there was such few technology in Ronchamp, something that he attributed to the hesitation of Europe in embracing industry and technology as America had already done. Albeit this waving attitude, Stirling consents that there are some industrial products such as the handrails which are important. He goes back to Renaissance and Mannerist to draw a parallelism with the rationale of the modern movement and this so-called "conscious imperfectionism (sic)" of Ronchamp to eventually state that "Le Corbusier, proceeding from the general to the particular, has produced a masterpiece of a unique bust most personal order."

The debate on Ronchamp can not be restricted to Europe although Italian architects were the main characters in the fruitful discussion as it has been seen until now. The coverage given to Ronchamp was of different extent. From covers in some journals to, surprisingly, absolute silence, it is an evidence that Le Corbusier was a world wide leading figure but, unlike other coetaneous masters such us Mies van der Rohe or Walter Gropius whose presence in American made them more relevant and present in American press, Le Corbusier was a bit far from that. So, if Architectural Forum gave its front cover to Ronchamp in September 1955 and an illustrated article 
titled "Le Corbusier builds a church", Progressive Architecture, on the other hand, did not even mention Ronchamp in an extensive illustrated report about churches and temples in September 1956.

John M. Jacobus Jr. writes "Le Corbusier: Fantasy and the International Style" to be published in February 1958 in arts \& architecture American journal. Jacobus mentions one of the latest books on Le Corbusier, a volume on illustrations and manifestos covering 1952-57 period in which there are more images of built works than drawings and text, something that satisfies Jacobus as it is the statement of Le Corbusier building rather than just drawing or writing. He points out Ronchamp as one of the most notable recent works by Le Corbusier and questions if it is a building that can be, though barely, tagged as rationalist or as "old International Style" or, on the contrary, it is the last manipulation of space that Le Corbusier was challenging for the last twenty years, that is to say, it is not a question of form, again, but of internal space, as pointed out by Bruno Zevi, and thus there is no such inconsistency with rationalism nor with modern architecture as this building, Ronchamp, although odd formally, is embedded in the discourse of modern architecture in the new terms set by recent authors.

There will be another article in arts \& architecture in which the influence of Ronchamp is still discussed. In June 1958, Craig Ellwood wrote "The Machine and Architecture" in which he claims Ronchamp to be a deep manifesto against the machine and also denounces the existence of too many pseudo-Ronchamps among us, which may threaten the need -he continues- of re-examine our recent motivations and those related to the machine to find out a way to a new architecture, a meaningful architecture.

\section{Conclusions. A brief historiography of Ronchamp in the History of Modern Architecture}

The publication of Ronchamp can be considered as the celebration of an event which lead to these very relevant in the context of the 1950s debates and discussions. Nonetheless, other authors and historians kept on reviewing the facts, buildings, contexts and facts to distill and filter what, eventually, would shape the, still, vast and unmanageable core of history of modern architecture.

Perhaps it is fair to say that the debate between Ernesto Nathan Rogers and Giulio Carlo Argan, though exciting and even beautiful and unrepeatable, has not been considered a key moment in history of modern architecture. Not even the participation of Bruno Zevi was enough to consolidate it as such and this can happen because maybe not enough attention has been paid to the material that historical journals provide us with whereas focus is put in other more well known debates with a clear and recognizable structure as those held in the successive Congrès International d'Architecture Moderne where minutes and books are produced and immediately are part of the body of knowledge that will feed the future histories of architecture. Same may be applied to exhibitions catalogues but unfortunately not to journals as they remain a sometimes obscure material that only researches investigate and pour in doctoral researches that hardly reach other fields.

To sustain the previous, some books will be useful as examples. One of the most important recents histories of modern architectures are due to Kenneth Frampton for several reasons. Not only Frampton's is the first critical history of modern architecture as stated in the title but it has also been studied by generations of architects and even today is one of the most, although maybe not didactical wise, studied in schools of architecture. Frampton compares Mies van der Rohe and Le Corbusier approaches to monumentality which were about technique in the case of Mies, and vernacular in the case of Le Corbusier. Frampton lies on James Stirling's texts for Architectural Review (despite not mentioning the journal, only the author) and how, according to Stirling, the design of Maisons Jaoul had hurt sensibilities of those who thought that modern architecture was only about smooth surfaces machinist inspired and placed in an articulated structural frame. In Frampton's opinion, 
Ronchamp takes Le Corbusier back to the thirties and his shifted interest (after War World II) to vernacular rather than classic. There is no mention to Argan/Rogers/Zevi debate in the whole book.

William Curtis' Modern Architecture Since 1900 is one of the books that more clearly supports the thesis of Ronchamp as an icebreaker for the second half of the century. Curtis pays good attention to what critics said when Ronchamp was built and he starts by saying that "its completion in 1954 (...) shocked the critics who flocked to see it". He goes on mentioning Pevsner complaint of a retreat into "irrationality" and Stirling dismayed by "conscious imperfections and mannerism". Curtis does not elude to give an explanation to the burst of Ronchamp and he goes back to Le Corbusier's paintings, his wooden sculptures of late 1950s, his sketches of shells and boats of early 1930s and, of course, the Pavillon Suisse. Besides, he clarifies again the non-religious nature of Le Corbusier and his idealistic approach to architecture and society, not stressing at all Argan's concerns about a master of modern architecture serving religious purposes. Curtis goes on with more references to explain Le Corbusier's attitude. These can be found in the writings of Ruskin and Art Nouveau to summarize it in "forms capable of a divine and magical character" and something called "primitive animism" in an effort to close the debate and bridge a new path to this kind of less masters-based histories of architecture.

As time passes, the relevance of these debates may seem to vanish and other issues are raised. In his Modern Architecture, Alan Colquhoun does not make any reference to the debate, which may surprise no one, but shockingly, he does not even write about Ronchamp except through Michelucci and his indirect reference to it in a chapter devoted to rationalism and organicism. This history reaches the second half of 20st century and, of course, Le Corbusier is a central figure despite the many precautions and annotations to draw new, more inclusive and contextualized histories less focus on central figures and more interested in an open and less dogmatic description of modernism.

However, there is room for other debates like the one about Neoliberty between Reyner Banham and Ernesto Nathan Rogers and its final episode at CIAM being Torre Velasca and Rogers (BBPR to be more specific) the main characters are also mentioned in the book by Colquhoun. In this sense, it is difficult to explain how a debate that started due to the publication in Casabella of some Italian -let's say local- minor works may still have a place in some histories of architecture whereas the one on Ronchamp is completely missed. Actors are more or less the same (Rogers and Banham -Neoliberty- Rogers and Argan -Ronchamp-) but buildings had a minimum impact in one case whilst a huge one in the other. Reasons again can be found in (apart from the fact that Torre Velasca was presented in CIAM) in the englishness of Reyner Banham and Alan Colquhoun and also in the ideas discussed in both polemic debates but, if we look closely to these issues, we find that Ronchamp was not an stylistic debate but a debate about the deep roots of modern architecture and its commitment to change the world while Neoliberty was a polemic about style and history. Nonetheless, what was in play was more importante in the case of the polemic between Banham and Rogers as, somehow, despite the violence of the Ronchamp dispute, this building and the course of modern architecure has been sanctioned some time before by Bruno Zevi and other architects working in the same line as Le Corbusier, though with less shocking resultssupported the openness of modern architecture to new outcomes and investigations about space and -as a resultform overcoming the stiffness of modern movement and rigid functionalism.

More recently, Anthony Vidler would quote James Stirling's "Le Corbusier's chapel and the crisis of the rationalism" in his Histories of the immediate present. In particular, in the chapter devoted to a mannerist modern movement, Vidler uses Stirling to draw the attention back to pure poetry expression and the abandon of functionalism in a shift to plasticity and pure space, which resembles some ideas from Bruno Zevi as well. This only means that the debate is still open and, albeit is widely accepted that Ronchamp is part of the History of Modern Architecture, it is still unclear whether it was only a milestone in Le Corbusier's work or its impact was 
larger. To some authors, this is a question that remains open but even more, the debate on the moral ground of modern architecture between Rogers and Argan had been re-opened again in 21st century by Paolo Portoghesi who, on the occasion of the intervention of Renzo Piano in Ronchamp, stated that Le Corbusier had a secret and profound faith in the mystery of life and perhaps in the sacred.

Perhaps the only certainty -if so- that histories may certify is that Ronchamp was not a question of form but of space and there were other buildings challenging rationalism at the same time and calling for an organic architecture. This is not what matters now, it is the very essence of the Modern Movement and the possibility of an architecture which could actually lead the world and inspire the society to major and dramatic changes, and for that there are no evidences yet as it is still under construction.

\section{Bibliography/references}

Cohen, Jean-Louis. The Future of Architecture. Since 1889. London: Phaidon, 2012.

Cohen, Jean-Louis. Manières de penser Ronchamp: Hommage à Michel Kagan. Editions de La Villette, 2012.

Colquhoun, Alan. Modern Architecture. Oxford University Press, 200

Curtis, William. Modern architecture since 1900. Phaidon, 1982.

Forty, A. Words and Buildings: a Vocabulary of Modern Architecture. Thames \& Hudson

Frampton, Kenneth. Modern Architecture: A Critical History. London: Thames and Hudson, 1980.

Ockman, Joan. Architecture Culture 1943-68. A Documentary Anthology. New York: Columbia Books of Architecture / Rizzolli, 1993.

Pevsner, Nikolaus. Pioneers of Modern Design. From William Morris to Walter Gropius. London: Faber\&Faber 1936.

Tournikiotis, Panayotis. The Historiography of Modern Architecture. Cambridge, Massachusetts: Massachusetts Institute of Modern Architecture, 1999.

Vidler, Anthony. Histories of the immediate present. Inventing architectural modernism. Massachusetts: MIT Press, Cambridge, 2008. 